\title{
KOMUNIKASI BUDAYA \\ DALAM TRADISI “MAKAN TAL” MELAYU
}

\author{
Ibrahim
}

\begin{abstract}
ABSTRAK
'Makan tal' adalah salah satu tradisi yang masih diamalkan oleh banyak masyarakat Melayu di Nanga Jajang. Tradisi ini dilakukan berkaitan dengan kelahiran seorang anak bayi dalam sebuah keluarga. Tradisi ini dipercayai oleh masyarakat Melayu Nanga Jajang sebagai berpengaruh terhadap kesehatan ibu dan bayinya hingga berakhirnya masa menyusui. Tradisi ini lebih identik dengan praktek menjaga kesehatan ibu dan bayi secara tradisional. Kajian ini mendapati setidaknya ada tiga jenis `makan tal’ di Nanga Jajang, yakni `tal angat` (panas), ‘tal colap`(dingin), dan `tal ntaradua` (sedang). Berdasarkan tinjauan komunikasi budaya, didapati sedikitnya 7 nilai yang terkandung dalam tradisi 'makan tal’ pada masyarakat Melayu, yakni; untuk pemulihan kesehatan ibu setelah melahirkan, untuk memperbanyak ASI, untuk kesehatan anak bayi, untuk menjaga keseimbangan alam, bernilai ekonomis, untuk menjaga kesehatan secara alamiah, serta untuk memelihara identitas diri dan keturunan.
\end{abstract}

Kata Kunci: makan ‘tal’, tradisi, nilai komunikasi budaya

\section{A. Pendahuluan}

"Makan tal" dalam tradisi Melayu: Satu tinjauan komunikasi budaya pada masyarakat Melayu Nanga Jajang, Ulu Kapuas adalah satu artikel yang disarikan dari sebuah laporan penelitian yang penulis lakukan tahun 2012 melalui projek kompetitif kelompok di lingkungan
Institut Agama Islam Negeri (IAIN) Pontianak. Dengan pendekatan ilmu komunikasi, khususnya komunikasi budaya dan antarbudaya, kajian ini memaparkan mengenai sebuah tradisi budaya yang hidup dan diamalkan oleh masyarakat Melayu di Nanga Jajang, bentuk dan bahannya, serta makna dan 
nilai yang terkandung dalam tradisi tersebut.

Dalam banyak konteks kita sering mendengar ungkapan yang bersifat penilaian terhadap prilaku hidup manusia sebagai bersifat manusiawi. Ungkapan tersebut memberikan gambaran bahwa adanya nilai-nilai tertentu dalam prilaku hidup yang senantiasa menyatu dalam diri manusia. Artinya bahwa manusia itu mesti menjalani hidup sesuai dengan nilai kemanusiaan dan atau fitrah diri manusia. Dalam konteks sosial, fitrah diri manusia adalah bersosialisasi, dimana kita senantiasa memerlukan keberadaan orang lain di sekitarnya.

Dalam konteks etika, fitrah diri manusia adalah makhluk yang beradab dan berbudaya. Fitrah diri inilah yang akhirnya melahirkan kebiasaankebiasaan hidup yang baik dan dipelihara sebagai budaya dan tradisi yang diwarisi dalam hubungan sosial kemanusiaan. Dengan fitrah itu pulalah manusia hidup saling memerlukan satu sama lain, hingga membentuk kelompok agama, etnik, ras dan sebagainya. Dan setiap kelompok akan melahirkan aturanaturan nilai sosial yang disepakati bersama yang disebut adat atau budaya ${ }^{1}$.

\footnotetext{
1 Adat atau budaya dalam masyarakat Melayu merupakan satu kebiasaan yang baik yang dipelihara bahkan diwarisi secara turun temurun. Karena itu setidaknya ada empat
}

Karena itu, setiap kelompok etnik, agama, ras dan sebagainya sesungguhnya hidup dalam tuntunan adat dan budayanya masing-masing yang dianggap baik dan dipelihara secara turun temurun, sebagaimana orang Menggala di Lampung Utara (lihat kajian Julia Maria, 1993), orang Trunyan di Bali (lihat dalam kajian Danandjaya, 1989) dan sebagainya. Tak terkecuali orang Melayu yang tersebar di belahan bumi kepulauan nusantara ini².

Sejarah memetakan bahwa sistem sosial masyarakat Melayu sangat terikat dengan adat dan tradisi yang diwarisi turun temurun. Segala sistem nilai dan norma yang menentukan pemikiran dan pola tingkah laku mereka sebenarnya telah diperturunkan melalui proses pembudayaan atau sosialisasi daripada generasi tua kepada generasi muda zaman berzaman (Kamarudin

tingkatan adat yang dikenal dalam masyarakat Melayu; pertama, adat yang sebenar adat atau adat asli (adat atau norma hukum syara'); kedua, adat yang diadatkan (hasil pemikiran terbaik para leluhur); ketiga, adat yang teradat (konvensi/kesepakatan masyarakat adat); keempat, adat istiadat yang ditradisikan (adat resam). Lihat dalam Wan Galib (2011), dan Elmustian Rahman dkk (2011).

2 Bahkan menurut Noriah Mohamed (2009), seseorang yang mengaku dirinya orang Melayu mesti beradat-istiadat Melayu, berbahasa Melayu, dan beragama Islam. Karena adatistiadat Melayu, bahasa Melayu dan agama Islam adalah suatu identiti kepribadian orang Melayu (Kamarudin Mohd. Balwi, 2005). Pendapat ini memperkuat bukti bahwa adat dan budaya merupakan aspek penting dalam lingkup sosial dan komunikasi masyarakat Melayu. 
Moh. Balwi, 2005: 69). Menurutnya, proses sosialisasi ini dilakukan oleh keluarga dan masyarakat secara keseluruhan. Segala sistem hidup mereka kuat berakar kepada nilai dan norma Islam yang mementingkan kesejahteraan sosial wujud dalam masyarakat.

Berdasarkan konsep di atas, kita dapat memahami bahwa budaya atau kebudayaan adalah meliputi keseluruhan cara hidup orang Melayu ${ }^{3}$, termasuk adat tradisi dan akal budinya (Noriah Mohamed, 2009: 76). Sebab itu, makna adat dengan budaya bagi orang Melayu saling melengkapi. Orang Melayu sering merujuk fenomena budayanya dengan ungkapan "ini adat kami" (Kamarudin Mohd. Balwi, 2005: 70).

Kemajuan pembangunan yang ditandai dengan perkembangan teknologi informasi dan komunikasi serta sumber daya manusia yang semakin meningkat, tidak serta merta menghilangkan tradisi sosial dalam masyarakat. Banyak dari tradisi dan budaya masyarakat yang masih bertahan dan terus hidup hingga saat ini. Sebagai contoh tradisi robo'robo`yang masih eksis dilakukan oleh masyarakat Melayu di Pontianak dan

Bukankah Erwadt T. Hall mendefinisikan budaya dalam konteks komunikasi antarbudaya sebagai The Total Way of Life of a People, composed of their learned and shared behavior patterns, values, norms, and material object (lihat dalam Rogers dan Steinfatt, 1999)

Mempawah, tradisi saprahan oleh Melayu Sambas (Erwin \& Andi Gidang, 2010). Kemudian untuk masyarakat Melayu di Nanga Jajang, kita masih menemukan banyak tradisi budaya yang masih eksis dan diamalkan seperti topung tawar, tradisi besunat kampung (Ibrahim, 2010a), tradisi pangil (Ibrahim, 2013), pantang larang (Ibrahim, Zaenudin dan Yusriadi, 2009), hingga tradisi 'makan tal' pada masyarakat Melayu Nanga Jajang.

\section{B. Nanga Jajang sebagai kawasan kajian}

Nanga Jajang, adalah nama sebuah perkampungan kecil setingkat dusun, yang terletak di pedalaman Ulu Kapuas, Kalimantan Barat. Kampung ini berada di pesisir Jalan Lintas Selatan menuju Kota Putussibau, tepatnya di kilometer 100. Jarak kampung Nanga Jajang dengan Kota Pontianak sekitar 650 KM. Sementara dengan kota Putussibau sekitar 100 KM. Dengan kemudahan transportasi saat ini, tidaklah terlalu sukar untuk berkunjung ke kampung ini, sebab ia berada di lintasan jalan utama yang menghubungkan Pontianak dengan Putussibau.

Sebagai salah satu
perkampungan Melayu tertua di
pedalaman Ulu Kapuas, Nanga Jajang
didiami oleh mayoriti etnik Melayu yang


berjumlah 345 jiwa (Ibrahim, Yusriadi \& Zaenudin, 2012: 42). Berdasarkan sejarahnya, Islam tumbuh dan berkembang dengan cukup kuat di perkampungan ini. Hal ini tampak dengan perkembangan keagamaan yang bercorakkan paham Ahlussunnah wal jama`ah (sunni). Sebagai penganut Islam Sunni, banyak tradisi lokal yang masih dijalankan oleh masyarakat muslim di Nanga Jajang (Ibrahim, 2010b). Artinya bahwa, ketika tradisi dan budaya tersebut dipandang baik dan tidak bertentangan dengan nilai-nilai ajaran keagamaan, maka ia terus dipelihara dan hidup dalam praktek masyarakat. Satu di antaranya adalah tradisi makan `tal'.

\section{Makan "Tal" dalam Tradisi Melayu}

'Makan tal' adalah satu istilah yang digunakan oleh masyarakat Melayu Nanga Jajang untuk menyebutkan kelengkapan tradisi yang diamalkan oleh setiap perempuan yang baru melahirkan. Tradisi tersebut dilaksanakan hingga anak berusia beberapa bulan setelah melahirkan, atau selama masa seorang ibu menyusui anak bayinya.

\section{Bentuk-bentuk 'Tal'}

Berdasarkan data lapangan, setidaknya ditemukan dua bentuk Tal yang masih diamalkan oleh masyarakat Melayu Nanga Jajang, yakni; ‘al’ yang dimakan/dimunim dan 'tal' yang disiram/untuk mandi.

a. 'Tal' yang dimakan/diminum.

Bentuk yang paling utama dari tradisi 'makan tal' pada masyarakat Melayu di Nanga Jajang adalah dengan cara dimakan atau diminum. 'Tal' yang dimakan atau diminum dibuat sebagaimana lauk-pauk dan sayur-mayur pada umumnya. Jika pada orang kebanyakan (umumnya) menu makan dengan lauk-pauk dan sayur-mayur yang tidak terlalu diatur (sesuai selera), maka menu makan (lauk-pauk dan sayur-mayur) pada seorang ibu yang mengamalkan tradisi 'makan tal' adalah sesuai dengan bahan-bahan yang telah ditentukan (lihat dalam sub kajian bahan-bahan 'tal'). Dan kesemua menu 'tal' ini adalah dengan cara dimakan dan atau diminum sebagaimana makan minum kita sehari-hari.

Hal ini tergambarkan dari jawaban seorang informan yang mengakui masih mengamalkan tradisi 'makan tal'.

"Tal iya' ada yang m:akan atau m:inum. Ada ga`yang dipakai mani’, untuk besiథam b:obah. lya` mih yang s:obut dengan 'tal' bobah. Jadi ada uФang yang tal ya' hanya untuk makan, ada ga` yang sampai pakai 
mani atau besiФam b:obah"4 (Cik Nah, temubual 2011)

\section{b. TAL yang disiram/untuk Mandi.}

Bentuk lain dari tradisi 'tal' pada masyarakat Melayu Nanga Jajang adalah dengan cara disiram airnya ke kepala (membasahi rambut kepala) dan atau dijadikan sebagai campuran air mandi (untuk mandi). Tradisi 'tal' untuk minum dan atau mandi ini biasanya disimbolkan dengan bahan santan kelapa (untuk 'tal dingin'), atau air rebus daun k:onang/longkan/аФа? (untuk 'tal angat` dan `tal ntaradua').

Dari sisi jenisnya, makanan Tal terdiri dari tiga, yakni 'tal angat' (hangat), 'tal colap' (dingin) dan 'tal ntaradua' (sedang). Berikut penjelasan dari masing-masing bentuk 'tal` tersebut.

\section{1). Tal Angat.}

'Tal angat' itu adalah makanan 'Tal' yang bersifat menghangatkan yang terdiri dari bahan-bahan yang menghangatkan seperti liyak merah atau sahang (merica-lada). Masyarakat pengamal makanan 'tal

\footnotetext{
${ }^{4}$ Maksudnya: 'Tal' itu ada yang dimakan dan atau diminum. Ada juga yang digunakan untuk mandi, bersiram kepalanya, yang disebut dengan 'tal' siram (bobah). Jadi, ada orang yang hanya mengamalkan 'tal' makan(dimakan), ada juga yang sampai untuk mandi atau siraman kepalanya.
}

angat percaya bahwa kondisi badan mereka dingin, karena itu harus memakan makanan yang dapat menghangatkan, hal ini dipercayai berpengaruh ke anak bayi mereka. Selain liyak merah dan sahang, bahan-bahan 'tal' hangat terdiri dari daun k:onang merah, abuk merah, dan salai (ikan atau ayam).

Sebagai bahan utama yang mengangatkan, jahe (liyak) merah dipercayai memiliki khasiat yang baik untuk ibu dan bayinya. Dalam pengobatan China, jahe merah dipercayai sebagai berkhasiat memperbaiki fungsi limpa kecil, lambung dan ginjal, sebagai obat perangsang dan pembantu bagi penderita impotensi. Jahe merah juga dipercayai mengandung minyak astiri yang tinggi, yang memberikan efek rasa hangat bagi tubuh sehingga bermanfaat untuk melegakan pernafasan bagi penderita asma, menyembuhkan migraine, pusingpusing, melancarkan peredaran darah, memperbaiki pencernaan, perut kembung, memecah gas dalam perut, mengobati encok dan pegal linu, serta meringankan Influenza (http://rumputeki.blogspot.com). 2). Tal Colap.

Sementara 'tal colap' adalah kebalikan dari 'tal angat'. 'Tal colap' 
adalah makanan yang dapat mendinginkan badan perempuan yang baru melahirkan. Sebab, masyarakat pengamal makanan 'tal colap` percaya bahwa kondisi badan mereka hangat, karena itu harus memakan makanan yang dapat mendinginkan, terutama ibu dan anak bayinya. Karena itu, bahan makanan ‘tal colap` itu terdiri dari daun longkan, abuk putih (klenci/coleus tuberosus), dan salai (ikan atau ayam). Kemudian yang paling membedakan makan 'tal colap' dengan 'tal angat' adalah digunakannya santan pada 'tal colap', baik untuk makan seperti masakan bersantan, maupun untuk bersiram kepala (b:obah).

\section{3).Tal Ntaradua}

'Tal ntaradua' maksudnya adalah makanan 'tal' yang tidak termasuk ke dalam katagori angat (hangat) dan tidak juga colap (dingin), melainkan pertengahan atau sedang. Makanan 'tal ntaradua' dalam tradisi Melayu Nanga Jajang bermakna bahwa seorang perempuan yang baru melahirkan boleh memilih untuk makan makanan yang dingin (tal colap') ataupun makanan yang hangat ('tal angat').

Pastinya, pengamal makanan 'tal ntaradua` tidak boleh makan makanan yang terlalu dingin (sebagaimana 'tal colap') atau terlalu hangat (sebagaimana 'tal angat'). Sebagai contoh pada pengamal makanan 'tal ntaradua' ini menurut mak $\mathrm{Ngah}^{5}$ (wawancara Agustus 2011) jika nasinya dingin, maka sebaiknya sayurnya mesti hangat. Atau, sebaliknya menurut Kamsiah (Agustus 2011) jika nasinya hangat, maka sebaiknya makan dengan sayur dingin. Begitulah makna makanan ‘tal ntaradua' dalam tradisi masyarakat Melayu di Nanga Jajang.

Sementara dari sisi bahan, 'tal ntaradua' tidak jauh berbeda dengan bahan makanan tal hangat atau dingin, kecuali liyak merah (pada 'tal angat') dan santan kelapa (pada `tal colap') yang tidak termasuk dalam bahan makanan 'tal ntaradua'. Jikapun ada bahan makanan yang dapat memberikan sedikit kehangatan pada seorang lbu yang baru melahirkan adalah ditambah dengan liyak bumbu (jahe putih).

Sebagai bahan makanan yang bisa memberikan rasa harum dan wangi dalam masakan, liyak bumbu (jahe putih) ini juga memiliki beberapa khasiat bagi kesehatan, antara lain menambah nafsu makan,

\footnotetext{
5 Almarhumah meninggal dunia pada 15 Februari 2013, semoga Allah menerima segala amal ibadahnya dan mengampuni segala dosa dan kesalahannya, amin.
} 
memperkuat lambung, memperbaiki pencernaan, memperkuat otot usus, serta pembersihan tubuh melalui keringat. Bahkan penelitian kesehatan modern menyebutkan bahwa jahe memiliki manfaat untuk menurunkan tekanan darah, dengan sifatnya yang antikoagulan jahe membantu pencernaan, menurunkan kolesterol dan mencegah penggumpalan darah, membuat lambung menjadi nyaman, juga mengandung antioksidan yang membantu menetralkan efek merusak yang disebabkan oleh radikal di dalam tubuh (http://mazerdo.wordpress.com)

\section{Kegunaan Makanan 'Tal'}

Berdasarkan hasil wawancara dengan beberapa informan di lapangan, dapatlah difahami beberapa kegunaan dari makanan 'tal', antara lain; supaya perempuan yang baru melahirkan merasa nyaman dan cepat kembali segar badannya, dan bisa menambah banyak air susu ibu. Pandangan tersebut tampak sejalan dengan beberapa pendapat mengenai pentingnya menjaga makanan dan memilih jenis makanan yang baik dan sehat bagi seorang ibu yang baru melahirkan dan dalam menyusui.

Menurut Shilpa Joshi (seorang ahli gizi) yang menekankan pentingnya mengonsumsi makanan yang mengandung minyak dan berbagai jenis bumbu serta rempah-rempah bagi ibu yang baru melahirkan, kecuali jika dilarang oleh dokter atau ahli gizi. Selain itu, seorang ibu yang baru melahirkan dan menyusui juga perlu asupan makanan yang mengandung cukup kalori, zat besi, kalsium, dan cairan. Karena itu dalam sebuah situs tentang kesehatan merekomendasikan 7 jenis makanan yang penting dikonsumsi oleh seorang ibu yang sedang dalam menyusui, yakni Salmon (yang mengandung DHA untuk perkembangan bayi), susu rendah lemak (yang mengandung protein, vitamin dan kalsium), daging sapi (yang mengandung zat besi \& pritein hewani), kacangkacangan (yang mengandung protein nabati), jeruk (yang mengandung vitamin C), telur ayam (yang mengandung DHA dan vitamin D) serta konsumsi banyak air putih untuk menghindari dehidrasi (http://food.detik.com)

Bahkan menurut Ketaki KarpeKolgaonkar (seorang clinical pharmacist) bahwa diet pasca melahirkan harus memenuhi semua kebutuhan nutrisi si ibu yang baru melahirkan. Berhati-hatilah terhadap sayuran yang belum dicuci karena masih mengandung bakteri, susu yang tidak dipasteurisasi, air yang tidak disterilkan atau daging mentah karena dapat mengganggu kesehatan si ibu 
(Times of India dalam http://obgynspots.blogspot.com).

Dengan demikian jelas bahwa, apa yang dipercayai oleh masyarakat Melayu Nanga Jajang terhadap tradisi 'makan tal' yang mereka amalkan memiliki kesesuaian dengan pandangan ilmu kesehatan modern, terutama nilainilai gizi dan asupan makanan penting bagi seorang ibu yang baru melahirkan dan kesehatan anak bayinya. Karena itulah mereka percaya bahwa makanan 'tal' dalam tradisi mereka adalah untuk memelihara kesehatan ibu dan anak bayinya, yang merupakan tujuan utama dari tradisi makan makanan tersebut.

\section{Eksistensi 'makan Tal' dalam Tradisi Melayu}

Sebagai sebuah tradisi yang baik, yang terus terpelihara eksistensinya secara turun temurun pada masyarakat Melayu di Nanga Jajang, sesungguhnya mempunyai landasan yang cukup kuat dalam terminologi agama (Islam). Dalam Islam misalnya dikenal istilah 'urf, atau kebiasaan-kebiasaan yang baik dan diamalkan oleh suatu masyarakat. Islam bukan saja mengakui kebiasaankebiasaan yang baik ('urf) itu dalam suatu masyarakat, melainkan menjadikan kebiasaan ('urf) tersebut sebagai salah satu landasan (sumber) hukum Islam, terutama menyangkut kepentingan nilai-nilai sosial suatu masyarakat yang tidak bertentangan dengan dasar normatif agama (Islam). Anjuran terhadap kebiasaan ini dengan jelas disebutkan dalam Q.S. Al-A`raf/7: $199^{6}$.

Berdasarkan ayat di atas, 'urf (wa'mur bil ‘urf) disamakan dengan istilah ma'ruf, yakni sesuatu yang dikenal dan dibenarkan oleh masyarakat, atau adat istiadat yang didukung oleh nalar yang sehat serta tidak bertentangan dengan ajaran agama (M. Quraish Shihab, 2004: 353). Bahkan lebih lanjut dalam tafsir Al-Misbahnya dijelaskan bahwa 'urf atau ma'ruf dalam ayat 199 itu adalah kebajikan yang jelas dan diketahui oleh semua orang, serta diterima dengan baik oleh manusiamanusia normal, atau yang disepakati sehingga tidak perlu didiskusikan apalagi diperbantahkan.

Dengan kata lain, 'urf menurut $\mathrm{M}$. Quraish Shihab adalah kebiasaan yang baik dan disepakati (hasil kesepakatan). Karenanya ia bersifat lokal dan temporal. Bersifat lokal artinya mungkin saja kebiasaan yang baik pada suatu masyarakat berbeda dengan kebiasaan yang baik menurut masyarakat yang lain.

\footnotetext{
${ }^{6}$ Khuzil afwa wa`mur bil `urf wa a`ridh `anil jahilin: Artinya: "Jadilah engkau pemaaf dan suruhlah orang mengerjakan yang ma`ruf (`urf), dan berpalinglah daripada orang-orang yang bodoh".
} 
Bersifat temporal artinya mungkin saja terjadinya pergeseran, perubahan dan perkembangan tentang kebiasaan yang dianggap baik sesuai dengan kesepakatan dalam masyarakat itu sendiri. Dalam konteks budaya, menurutnya, kita dapat memahami ungkapan "apabila ma'ruf ('urf) kurang diamalkan, maka dia menjadi mungkar; dan apabila mungkar telah tersebar, maka dia bisa menjadi ma 'ruf' (M.Quraish Shihab, 2004: 353).

Mengikuti pernyataan M. Quraish Shihab dalam memberikan tafsiran terhadap istilah 'urf sebagaimana di atas, memberikan kesan bahwa tradisi 'makan tal' sesungguhnya termasuk sesuatu yang baik ('urf/ma'ruf) ketika kebiasaan ini terus diterima dan disepakati oleh masyarakat penggunanya di satu sisi, dan pada sisi lain ia tidak bertentangan dengan nilai-nilai yang diajarkan dalam agama. Dengan inilah kebiasaan 'makan tal’ terus hidup dan eksis dalam tradisi masyarakat Melayu Nanga Jajang hingga masa ini.

\section{Komunikasi budaya dalam tradisi makan "Tal"}

Sebagai sebuah tradisi yang hidup dan berkembang dalam sistem sosial suatu masyarakat, tentunya 'makan tal' memiliki maksud dan tujuan tertentu. Semakin jelas karakteristik budaya sebuah masyarakat, maka akan semakin pasti adanya makna tertentu dalam setiap budaya dan tradisi yang hidup dan berkembang bersamanya, termasuklah dalam konteks ini tradisi 'makan tal’ masyarakat Melayu di Nanga Jajang, Ulu Kapuas.

\section{1. 'Makan Tal dan Hubungannya dengan Teori Valensi}

Jika dalam tradisi `makan tal` kita menemukan katagorisasi 'tal colap' (dingin) dan 'tal angat' (panas). Bahkan ada satu lagi katagori yang sedang hangat dan dingin yang disebut masyarakat setempat dengan 'tal ntaradua' (sedang). Maka dalam teori valensi ${ }^{7}$ disebutkan bahwa penyakit yang diderita oleh manusia dapat dikelompokkan kepada beberapa kelompok, baik bersifat personalistik maupun yang bersifat naturalistik (Julia Maria, 1993: 66). Dari sinilah menurutnya muncul unsur-unsur panas atau dingin

\footnotetext{
7 Menurut Kubik Training dan Consultancy, valensi adalah "bobot" atau "takaran" yang mewakili keseluruhan kapasitas diri, dimana setiap orang memiliki tingkat valensi yang berbeda-beda. Sebagai sebuah teori, valensi memiliki banyak makna sesuai konteksnya. Dalam konteks psikologi sosial valensi adalah kapasitas yang dimiliki seseorang yang menentukan kualitas hasil usahanya dan mempengaruhi tingkat sukses orang tersebut. Menyangkut kesehatan, agaknya makna valensi yang paling sesuai adalah dalam kontek kimia, yakni elektron-elektron sebuah atom yang dapat membentuk ikatan kimia dengan atom lainnya (lihat dalam Wikipedia, akses 13/09/2013).
} 
yang dapat menyebabkan seseorang menderita sakit dalam teori valensi, sebagaimana dipercayai oleh orang Manggala di Lampung Selatan.

Teori valensi panas-dingin yang dipercayai sebagai penyebab suatu penyakit ini menurut Lee (1982) sesungguhnya mirip dengan teori yinyang dalam kepercayaan Cina. Hawa panas dan pengaruh panas, serta hawa dingin dan pengaruh dingin dapat berasal dari makanan, barang, udara dan lingkungan psikologis (dalam Julia Maria, 1993: 63).

\section{Nilai-Nilai Komunikasi Budaya dalam Tradisi 'Makan Tal'}

Berdasarkan data lapangan dan analisis yang penulis lakukan, kajian ini menemukan sedikitnya tujuh nilai komunikasi budaya yang terkandung dalam tradisi makan 'tal' pada masyarakat Melayu Nanga Jajang, yakni:

a. Untuk Pemulihan Kesehatan Ibu Setelah Melahirkan

Melahirkan, adalah sebuah proses perjuangan yang luar biasa berat bagi seorang ibu. Sebab, dalam proses itu, seorang ibu ibaratnya sedang bertarung antara hidup dan mati. Untuk melewati proses melahirkan ini seorang ibu sesungguhnya telah mempertaruhkan jiwa dan raganya, mental dan fisiknya.
Karena itu, wajar jika kondisi seorang ibu begitu lemah setelah melahirkan, tenaganya begitu terkuras untuk melahirkan seorang anak bayi dari rahimnya.

Beratnya perjuangan seorang ibu dalam melahirkan merupakan salah satu alasan yang membuat kedudukan ibu sangat tinggi bagi anak-anaknya. Allah Swt dengan tegas memerintahkan setiap anak untuk senantiasa menghormati dan menghargai orang tuanya, terutama ibunya yang telah mengandungnya dalam keadaan lemah, hingga menyusui dan menyapihnya (Q.S. Luqman/31: 148). Bahkan dalam sebuah Hadits disebutkan bahwa surga Allah berada di bawah telapak kaki ibu (al-jannatu tahta aqdamil ummahat ${ }^{9}$.

Dalam dunia medis dijelaskan bahwa, untuk proses melahirkan, seorang ibu telah mengalami

Maksudnya: "Dan kami perintahkan kepada manusia (berbuat baik) kepada dua orang ibubapaknya; ibunya yang telah mengandungnya dalam keadaan lemah bertambah-tambah, dan menyapihnya dalam dua tahun. Bersyukurlah kepadaKu dan kepada ibu-bapakmu, hanya kepadaKu lah kembalimu" (Q.S. Lukman/31: 14)

9 Artinya: Surga itu ada di bawah telapak kaki Ibu (al-Hadits). Hadits ini menunjukkan bahwa, kasih sayang dan keridhaan ibu akan mampu mengantarkan seorang anak meraih surga Allah Swt. Sebaliknya, kemurkaan seorang ibu akan menjadi penghalang ke surga bagi seorang anak manusia (lihat kandungannya dalam hadits Nabi Saw) 
pengerahan fisik yang luar biasa, hingga menyebabkan beberapa syaraf-syaraf kecil dalam tubuhnya terputus. Oleh karena itu, seorang ibu harus segera menjalani perawatan untuk pemulihan tenaganya, dan penyembuhan syaraf-syaraf yang terputus pada saat kontraksi melahirkan. Untuk proses inilah ibuibu yang baru melahirkan diharuskan mengkonsumsi makanan yang sehat, bergizi dan mengandung zat-zat yang diperlukan oleh tubuh.

Beberapa makanan yang penting dikonsumsi oleh seorang ibu setelah melahirkan antaranya adalah yang mengandung kalori, zat besi dan kalsium. Menurut Silpha Joshi (ahli gizi berkebangsaan India), "Ibu membutuhkan energi ekstra, setidaknya dalam enam bulan pertama karena ia akan menyusui bayi lebih sering. Jadi dia perlu lebih banyak kalori yang ada pada makanan yang kaya protein,"

Melihat kepada tradisi 'makan tal', maka sesungguhnya keperluan zat-zat makanan untuk pemulihan kesehatan seorang ibu setelah melahirkan juga sudah terpenuhi dalam makanan 'tal' masyarakat Melayu di Nanga Jajang seperti ikan salai, daging, dan beberapa sayurannya. b. Untuk Memperbanyak ASI

ASI adalah makanan terbaik untuk bayi, karena itu dianjurkan kepada setiap ibu untuk memberi makan anaknya dengan ASI secara ekslusif. Karena itu, seorang ibu harus memahami cara-cara meningkatkan produksi ASI dan menjamin kualitasnya. Sebab ASI yang memadai dan kualitasnya yang baik akan sangat berpengaruh pada kesehatan dan perkembangan anak bayinya.

Jika mengacu pada perkembangan ilmu pengetahuan modern, sumber-sumber makanan tersebut bisa didapatkan dari produkproduk susu khusus ibu menyusui yang beredar di pasaran. Akan tetapi sebenarnya, peningkatan produksi ASI bagi ibu yang baru melahirkan juga dapat diperoleh dari makanan 'tal' yang masih diamalkan oleh masyarakat Melayu di Nanga Jajang. Sebut saja misalnya dari bahan Umbi, kelapa (bunganya hingga air santannya), dan lain-lain.

c. Untuk Kesehatan Anak Bayi Menjamin anak bayi berkembang dengan baik dan tumbuh dengan sehat adalah perjuangan berikutnya bagi seorang ibu. Oleh karena itu, seorang ibu harus bisa menjaga dengan baik makanan yang 
dikonsumsinya. Makanan dimaksud bukan saja mempertimbangkan kesehatan ibu pasca melahirkan dan peningkatan produksi ASI, melainkan juga tidak berdampak buruk terhadap diri anak bayi. Sebab, anak bayi umumnya hanya makan dari ASI secara ekslusif.

'Makan tal' dengan salah satu bahan santan kelapa, atau bunga kelapa (pusuh) dan jantung pisang (tungkul) adalah untuk menambah air susu ibu dan menyehatkan bagi bayi yang meminumnya. Pentingnya memperhatikan makanan bagi seorang ibu yang menyusui dan kesehatan bayinya juga berlaku dalam tradisi masyarakat Trunyan di Bali, dimana sejak hamil hingga melahirkan dan menyusui, makanan seorang ibu harus betul-betul dijaga supaya tidak menjadi penyakit bagi bayinya (lihat dalam Danandjaya, 1989: 478).

$$
\text { Berdasarkan }
$$

ilmu pengetahuan modern dan perkembangan medis, kita dapat menemukan beberapa makanan yang dianjurkan untuk seorang ibu menyusui dan diyakini dapat menjamin kesehatan bayinya seperti minuman suplemen, susu rendah lemak, serta makanan-makanan yang mengandung kalori, kalsium dan vitamin.
Semua zat dalam makanan tersebut sesungguhnya terdapat dalam makanan 'tal' pada masyarakat Melayu di Nanga Jajang. Seorang ibu menyusui bisa memerlukan 200 hingga 500 ekstra kalori dalam rangka untuk mengakomodasi kemampuannya dalam hal menyusui (Republika Online, 2/9/2013).

\section{d. Untuk Menjaga Keseimbangan Alam}

Alam sesungguhnya telah menyediakan semua yang diperlukan oleh manusia. Karena itu, kita mesti percaya pada firman Allah yang mengatakan bahwa segala yang ada di langit dan di bumi diciptakan untuk dimanfaatkan secara baik dan berguna oleh manusia (Q.S. Luqman/31: $20^{10}$ ). Alam, dalam hal ini tumbuh-tumbuhan merupakan sumber kehidupan yang dibutuhkan oleh tubuh manusia. Oleh karena itu, pemanfaatan alam secara baik dan benar merupakan suatu keharusan bagi kelangsungan hidup manusia.

Pemanfaatan sumber daya alam dengan baik, yang bukan hanya mengambil manfaat darinya, tetapi

10 Maksudnya: "tidakkah kamu perhatikan sesungguhnya Allah telah menundukkan untuk (kepentingan) mu apa yang di langit dan apa yang di bumi dan menyempurnakan untukmu nikmat-Nya lahir dan bathin. Dan diantara manusia ada yang membantah (keesaan) Allah tampa ilmu pengetahuan atau petunjuk dan tampa kitab yang memberi penerangan" (Q.S. Lukman/31: 20) 
juga memelihara dan merawatnya demi kelangsungan ekosistem alam ciptaan-Nya adalah suatu kemestian untuk dilakukan oleh orang-orang yang beriman. Sebab, salah satu tugas ke-khalifahan manusia dalam misi penciptaan-Nya adalah kemampuan setiap manusia dalam mengambil manfaat secara baik dari alam, memelihara dan menjaganya. Sebab, jika tanggung jawab ini diabaikan, tidak mustahil akan terjadinya kerusakan alam dan segala isinya, hilangnya ekosistem alam yang baik, dan sebagainya. Karena itu Allah Swt sangat membenci perilaku manusia yang hanya tahu mengeksploitasi alam, tampa peduli memeliharanya, apapun alasannya (lihat Q.S. Ar-Rum/30: $41^{11}$ ).

Tradisi 'makan tal' pada masyarakat Melayu di Nanga Jajang sesungguhnya merupakan realisasi dari pemanfataan sumber daya alam dan pemeliharaan keseimbangan ekosistemnya. Sebab, semua bahan yang digunakan dalam tradisi 'makan tal' adalah bersumber dari alam (tumbuh-tumbuhan).

Dengan demikian, apa yang dilakukan oleh

\footnotetext{
11 Maksudnya: "telah nampak kerusakan di darat dan di laut disebabkan karena perbuatan tangan manusia, supaya Allah merasakan kepada mereka sebagian dari (akibat) perbuatan mereka, agar mereka kembali (ke jalan yang benar)" (Q.S. Ar-Rum/30: 41).
}

masyarakat Melayu di Nanga Jajang hari ini dengan tradisi 'makan tal' adalah satu upaya memelihara keseimbangan alam jagat raya ini.

e. Bernilai Ekonomi

Perkembangan dunia modern dengan ilmu pengetahuan dan teknologi yang luar biasa pesat telah melahirkan berbagai produk, termasuk bahan makanan. Artinya bahwa, untuk kebutuhan makan, hampir semua jenis dan rasanya sudah tersedia dalam kemasan modern di supermarket-supermarket, termasuk untuk ibu menyusui. Bahkan berbagai pilihan makanan tersebut juga tersedia dengan ragam kualitas yang kesemuanya tentu sudah melalui proses pengolahan pabrik, dengan harganya pun bersaing, bahkan cenderung menuntut kemampuan ekonomi yang memadai. Karena itu, tidak semua orang mampu menjangkau tuntutan ekonomi yang demikian. Tidak semua ibu melahirkan dan menyusui mampu membeli produk-produk tersebut.

Sementara apa yang diamalkan oleh masyarakat Melayu Nanga Jajang melalui tradisi 'makan tal menunjukan bahwa tradisi ini sangat ekonomis. Untuk memenuhi kebutuhan makanan yang baik dan sehat bagi ibu menyusui tidak 
memerlukan biaya yang mahal sebagaimana dalam masyarakat modern perkotaan, sebab alam telah menyediakan semuanya untuk mereka. Karena itulah, mengolah makanan 'tal' menjadi pilihan yang bernilai ekonomis bagi mereka hingga masa ini.

\section{f. Menjaga Kesehatan Secara Alamiah}

Dari sisi makanan, kesehatan seseorang sesungguhnya juga ditentukan oleh dua hal; pertama, sumber makanan yang dikonsumsinya; kedua, proses pengolahan makanan yang dikonsumsi. Dari sisi sumber, makanan instan yang dijual di supermarket umumnya dihasilkan dari bahan yang direkayasa (olahan). Kemudian sumber bahan ini selanjutnya dibuat melalui proses pabrik. Karena itu, besar kemungkinan adanya proses kimiawi di dalamnya seperti pewarna buatan, penyedap rasa, hingga pengawet makanan.

Sementara pada makanan 'tal', semua bahannya bersumber dari alam, diambil langsung dari tumbuhtumbuhan hijau yang hidup secara alami. Bahan itu selanjutkan diproses secara alamiah pula. Karena itu, makanan 'tal' terjamin bebas dari proses kimiawi, dan kesehatan yang didapatpun tentu sangat alamiah dan terbebas dari efek kimiawi.

Dengan demikian jelas bahwa pemeliharaan kesehatan ibu dan anak dalam konsep 'makan tal' sesungguhnya sama dengan prinsip oposisi pengobatan tradisional umumnya sebagai upaya mengembalikan kondisi suhu badan ke arah netral (Julia Maria, 1993: 86). Makan 'tal dingin' bagi yang suhu badannya tergolong panas. Makan `tal hangat bagi yang suhu badannya tergolong dingin, dan atau makan 'tal ntaradua' bagi suhu badan yang tidak terlalu panas atau dingin.

g. Untuk Memelihara Identitas Diri dan Keturunan

Satu hal yang paling menarik dan sangat istimewa dari tradisi 'makan tal' ini adalah merupakan satu bentuk pemeliharaan identitas diri dan keturunan pengamalnya. Artinya bahwa, tidak semua masyarakat Melayu di Nanga Jajang mengamalkan pola makan 'tal' yang sama. Pada satu keluarga (keturunan) mungkin mengamalkan makan 'tal hangat', sementara keluarga yang lain makan 'tal dingin' atau 'tal ntaradua'. Artinya bahwa seseorang yang berasal dari keturunan makan tal dingin` tidak boleh beralih ke makan 
'tal hangat' atau 'tal ntaradua', begitu sebaliknya.

Kajian di lapangan mendapati bahwa, pilihan jenis makanan 'tal' pada suatu keluarga bergantung pada garis keturunan keluarga tersebut. Pada keluarga yang mengamalkan makan 'tal dingin', keturunannya juga akan mengamalkan makan 'tal dingin`. Begitupun pada mereka yang makan `tal hangat' dan 'tal ntaradua'.

Akan tetapi, bagaimana dengan sebuah keluarga (suami-isteri) yang berasal dari keturunan makan 'tal' yang berbeda. Misalkan sebelumnya seorang isteri memiliki keturunan makan 'tal dingin', kemudian menikah dengan suami yang berasal dari makan 'tal hangat', maka ia harus mengikuti kebiasaan dari suaminya, harus makan 'tal hangat`. Jadi, yang memiliki garis keturunan jenis makanan 'tal' pada masyarakat Melayu di Nanga Jajang adalah mengikuti laki-laki atau suami (patrilinial), sebab ialah yang mewarisi tradisi tersebut dalam kepercayaan masyarakat Melayu Nanga Jajang. Hal ini dapat dipahami dari pernyataan Icu Wati ketika peneliti tanya mengenai ketentuan seseorang harus makan 'tal angat' atau 'tal colap', atau 'tal ntaradua`.

\section{E. Penutu}

'Makan tal' adalah salah satu tradisi yang masih diamalkan oleh masyarakat Melayu di Nanga Jajang, yang berkaitan dengan kelahiran seorang anak bayi dalam sebuah keluarga. Tradisi ini dipercayai oleh masyarakat Melayu Nanga Jajang memiliki pengaruh terhadap kesehatan ibu dan bayinya hingga masa menyusui selesai. Karena itu, tradisi ini lebih identik dengan praktik menjaga kesehatan ibu dan bayi secara tradisional.

Adapun bahan yang digunakan dalam tradisi 'makan tal' pada masyarakat Melayu Nanga Jajang antara lain daun k:onang, daun ubai, longkan, atau bisa juga dengan daun k:onang, atau daun ubai(salam)/bungkang, terus liyak padi atau liyak merah (Zingiberaceae Officinale Roscoe), atau liyak botung, abuk putih atau yang dikenal dengan Kentang Jawa (klenci/Coleus tuberosus), salai (ayam atau ikan). Bahan-bahan tersebut dimasak dan dimakan sebagaimana layaknya makan sehari-hari. Untuk jenis tertentu, makan 'tal' tersebut juga ada yang diiringi dengan mandi dan bersiram. Karena itu secara umumnya ada tiga jenis makan 'tal' di Nanga Jajang, yakni 'tal angat' (panas), 'tal colap' (dingin), dan `tal ntaradua' (sedang). 
Tradisi 'makan tal' masih terus diamalkan oleh masyarakat Melayu di Nanga Jajang, dikarenakan ada banyak nilai (komunikasi dan budaya) yang mereka percayai sebagai terkandung dalam tradisi tersebut. Kajian ini mendapati sedikitnya tujuh nilai komunikasi budaya dalam tradisi 'makan tal' pada masyarakat Melayu Nanga Jajang, yakni: untuk pemulihan kesehatan ibu setelah melahirkan, untuk memperbanyak ASI, untuk kesehatan anak bayi, untuk menjaga keseimbangan alam, untuk alasan ekonomi (bernilai ekonomis), untuk menjaga kesehatan secara alamiah, serta untuk memelihara identiti diri dan keturunan.

Dalam konteks kesehatan dan budaya, tradisi 'makan tal' merupakan kearifan lokal masyarakat dalam memelihara kesehatan secara alamiah dan tradisional, bersumberkan pada sumber daya alam yang telah diciptakan oleh Tuhan yang maha kuasa.

\section{F. Daftar Pustaka}

Danandjaya, James. 1989. Kebudayaan Petani Desa Truyan di Bali. Jakarta: UI Press.

Erwin \& Andi Gidang. 2010. Tradisi yang Membelajarkan: Mengurai unsurunsur Pendidikan dalam tradisi Tepung Tawar Melayu Sambas. Dalam Ibrahim MS. 2010. Tradisi dan Komunikasi Orang Melayu. Pontianak: STAIN Press dan Malay Corner.
Ibrahim. 2013. Makan 'Tal' dalam tradisi Melayu. Laporan Penelitian Kompetitif Kelompok DIPA Tahun 2013, Pontianak: P3M STAIN Pontianak.

Ibrahim. 2010a. Tradisi dan Komunikasi Orang Melayu. Pontianak: STAIN Pontianak Press dan Malay Corner.

Ibrahim. 2010b. Islam dan Tradisi di Nanga Jajang. Makalah yang disampaikan dalam Konferensi Antarabangsa Islam Borneo (KAIB) ke III, STAIN Pontianak, 4 s/d 5 Oktober 2010

Ibrahim, Yusriadi \& Zaenuddin. 2009. Kearifan Komunikasi dalam Pantang Larang Melayu Di Nanga Jajang. Laporan Penelitian. Proyek DIPA STAIN Pontianak.

Ibrahim, Yusriadi \& Zaenuddin. 2012. $\begin{array}{llr}\text { Pantang } & \text { Larang } & \text { Melayu } \\ \text { Kalimantan } & \text { Barat. Pontianak: } \\ \text { STAIN Press. } & & \end{array}$

Julia Maria. 1993. Kebudayaan Orang Menggala, Jakarta: UI Press.

Kamarudin Mohd. Balwi. 2005. Peradaban Melayu. Johor: Universiti Teknologi Malaysia, Skudai.

M. Quraish Shihab. 2004. Tafsir AlMisbah. Jakarta: Lentera Hati. Volume 5

Noriah Mohamed. 2009. Benang Sari Melayu-Jawa. Bangi: ATMA, UKM Ampang Press.

Rogers \& Stienfatt. 1999. Intercultural Communication. Wavelan Press: Witted State of Amerika.

\section{Sumber Internet:}

Elmustian Rahman dkk. 2011. Adat dalam tradisi Melayu di Riau. http: //www. tamadunmelayu.info. Diakses 16 Mei 2012

Republika.co.id., Washington. Makanan Sehat dan Tak Sehat untuk lbu Menyusui (2). Republika Online.co.id. diakses, Senin 2 September 2013.

Wan Ghalib. 2011. Adat Istiadat dalam Pergaulan Orang Melayu. 
http://www. adicita.com/ artikel. Diakses tanggal 16 Mei 2012.

Rumputeki.blogspot.com. Manfaat Jahe Merah bagi Kesehatan.

http://rumputeki.blogspot.com/2011

/06/manfaat-jahe-merah-bagi-

kesehatan-jahe.html. Diakses 12

Oktober 2012.

Shilpa Joshi. Dikutif dalam

http://food.detik.com. Akses 12

Oktober 2012
Time of India, dikutif dalam http://obgynspot.blogspot.com.

Akses 12 Oktober 2012.

http://mazerdo.wordpress.com. Akses 12 Oktober 2012.

Kubik Training dan Consultancy dalam http://wikipedia.com. Akses 13/09/2013 